\title{
Paradoxical bone mineralisation in the twin to twin transfusion syndrome
}

\author{
N J Bishop, F J King, P Ward, J M Rennie, A K Dixon
}

MRC Dunn Nutrition Unit, Dunn Nutritional Laboratory,

Downhams Lane,

Milton Road,

Cambridge CB4 1XJ

N J Bishop

F J King

Department of

Paediatrics,

Addenbrookes Hospital,

Cambridge

P Ward

J M Rennie

Department of Radiology,

Addenbrookes Hospital

and University of

Cambridge

A $\mathrm{K}$ Dixon

Correspondence to:

Dr Bishop.

Accepted 23 March 1990

(Arch Dis Child 1990;65:705-6)

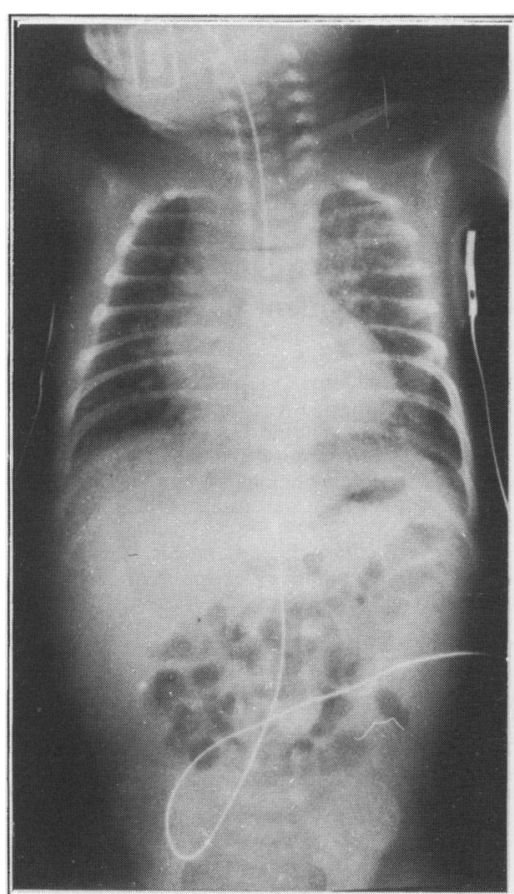

Twin 1
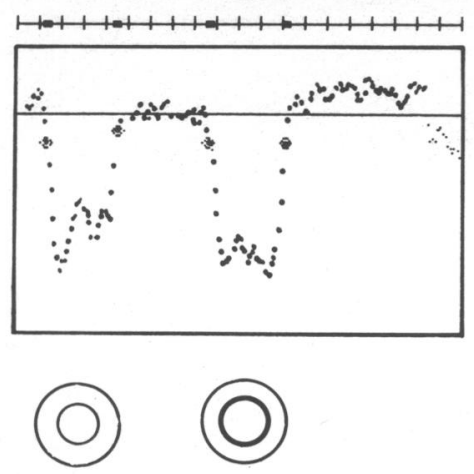

\begin{abstract}
We report twin preterm infants with the twin to twin transfusion syndrome, exhibiting grossly different bone densities on chest radiographs. Photonabsorptiometry showed the polycythaemic twin was osteopenic and the anaemic twin osteosclerotic; bone mineral contents were $0.028 \mathrm{~g} / \mathrm{cm}$ and $0.074 \mathrm{~g} / \mathrm{cm}$ respectively (normal mean (SD) 0.041 (0.006) g/cm. We speculate that alterations in macrophage derived osteoclastic activity contribute to these previously unreported findings.
\end{abstract}

The twin to twin transfusion syndrome is a well recognised clinical entity, occurring in approximately $7 \%$ of twin pairs. ${ }^{1}$ An asymmetry of blood flow from the common placental bed,

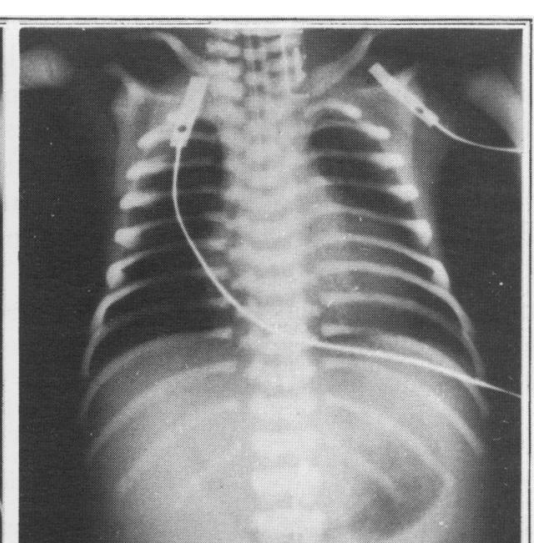

Case reports

Twin girls were delivered at 31 weeks' gestation by emergency caesarean section, the indications being maternal pre-eclampsia and fetal distress. Twin 1 weighed $1972 \mathrm{~g}$, and was plethoric (haemoglobin concentration $249 \mathrm{~g} / \mathrm{l}$, white cell count $24.3 \times 10^{9} / 1$, macrophages $2 \cdot 2 \times 10^{9} / 1$, and packed cell volume $0 \cdot 88$ ). Twin 2 weighed $1591 \mathrm{~g}$ and was pale (haemoglobin concentration $49 \mathrm{~g} / 1$, white cell count $5 \cdot 0 \times 10^{9} / 1$, macrophages $0.93 \times 10^{9} / 1$, and packed cell volume $\left.0 \cdot 18\right)$. Both infants required intubation at birth, and were ventilated to age 12 hours. The polycythaemic twin received two dilutional exchange transfusions with plasma, and the anaemic twin a single partial exchange with packed red blood cells.

Differences in bone density were noted on routine chest radiographs, twin 1 having osteopenic and twin 2 sclerotic bones. The growth plates appeared normal in both twins, and there were no subperiosteal resorption pits or fractures. Further investigations of bone mineral content were carried out using a Lunar SP2 (Lunar Radiation Corporation) photonabsorptiometer, on the left forearm at the $1 / 3 \mathrm{rd}$ distal site. Anthropometry comprised crown-heel length to the next succeeding $1 \mathrm{~mm}$ using a Holtain Neonatometer, weight to the nearest $10 \mathrm{~g}$ using Secca electronic balance scales, ulnar length to the next succeeding $0 \cdot 1 \mathrm{~mm}$ using RS Precision Vernier Calipers, and occipitofrontal circumference to the next succeeding $1 \mathrm{~mm}$ using a paper tape measure.

The infants were scanned and measured initially at age 1 week, and followed up at 6 weeks actual postnatal age, and at 3 and 9

Twins 1 and 2: initial radiographs, scan pictures, and extrapolated cross sectional bone/profiles.

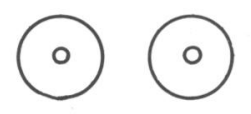

possibly in association with vascular stenosis, ${ }^{2}$
results in polycythaemia in one twin and anaemia in the other, with a significant difference in weight at birth of more than $20 \%$ of the

The mortality of such twin pairs is high and non-verbal ability at follow up for the smaller twin, where intrapair weight birthweight differ-

There is very little information available to accompany the profound haematological inequalities between the infants, and we report here the evidence for a significant alteration in bone mineral homoeostasis in this condition. 
Bone mineral content and anthropometry

\begin{tabular}{|c|c|c|c|c|c|c|c|}
\hline Age & & $\begin{array}{l}\text { Length } \\
(\mathrm{cm})\end{array}$ & $\begin{array}{l}\text { Ulnar } \\
\text { length } \\
(\boldsymbol{m m})\end{array}$ & $\begin{array}{l}\text { Weight } \\
(\mathrm{g})\end{array}$ & $\begin{array}{l}\text { Occipitofrontal } \\
\text { circumference } \\
(\mathrm{cm})\end{array}$ & $\begin{array}{l}\text { Bone mineral } \\
\text { content } \\
(\mathrm{g} / \mathrm{cm})\end{array}$ & $\begin{array}{l}\text { Bone } \\
\text { width } \\
\text { (cm) }\end{array}$ \\
\hline $\begin{array}{l}1 \text { Week } \\
10 \text { Weeks } \\
3 \text { Months } \\
\text { Corrected } \\
9 \text { Months } \\
\text { Corrected }\end{array}$ & $\begin{array}{l}\text { Twin } 1 \\
\text { Twin } 2 \\
\text { Twin } 1 \\
\text { Twin } 2 \\
\text { Twin } 1 \\
\text { Twin } 2 \\
\text { Twin } 1 \\
\text { Twin } 2\end{array}$ & $\begin{array}{l}45 \cdot 0 \\
42 \cdot 0 \\
51 \cdot 6 \\
47 \cdot 8 \\
57 \cdot 0 \\
57 \cdot 0 \\
70 \cdot 4 \\
70 \cdot 9\end{array}$ & $\begin{array}{r}66 \cdot 3 \\
62 \cdot 9 \\
79 \cdot 5 \\
71 \cdot 6 \\
82 \cdot 3 \\
81 \cdot 4 \\
104 \cdot 2 \\
100 \cdot 8\end{array}$ & $\begin{array}{l}1656 \\
1425 \\
3380 \\
2960 \\
4700 \\
4800 \\
8160 \\
8250\end{array}$ & $\begin{array}{l}28 \cdot 7 \\
28 \cdot 1 \\
34 \cdot 8 \\
35 \cdot 4 \\
39 \cdot 5 \\
40 \cdot 9 \\
46 \cdot 0 \\
46 \cdot 8\end{array}$ & $\begin{array}{l}0.028 \\
0.074 \\
0.041 \\
0.054 \\
0.080 \\
0.072 \\
0.123 \\
0.131\end{array}$ & $\begin{array}{l}0.422 \\
0.424 \\
0.496 \\
0.440 \\
0.632 \\
0.569 \\
0.655 \\
0.702\end{array}$ \\
\hline
\end{tabular}

months corrected age. The initial radiographs, scan pictures, and extrapolated cross sectional bone profiles are shown in the figure; the anthropometry and scan results are given in the table.

There were significant initial differences in crown-heel length and single bone (ulnar) length, in additional to the difference in birth weight. The bone mineral content estimation of $0.028 \mathrm{~g} / \mathrm{cm}$ for the larger twin was low (normal at this postconceptional age is mean (SD) 0:041 $(0.006) \mathrm{g} / \mathrm{cm}),{ }^{4}$ and that of the smaller twin substantially increased at $0.074 \mathrm{~g} / \mathrm{cm}$, a 2.5 fold difference overall.

The inequalities in mineral homoeostasis were further illustrated by biochemical measurements. Twin 1 had a progressive rise in plasma calcium concentration from birth, reaching $3.2 \mathrm{mmol} / \mathrm{l}$ at age 1 week, with a low plasma phosphate of $0.75 \mathrm{mmol} / \mathrm{l}$, and raised plasma alkaline phosphatase activity $(668 \mathrm{U} / 1$, adult normal range $<120 \mathrm{U} / \mathrm{l}$ ) at that time. Twin 2 demonstrated a normal decrease in plasma calcium to $1.83 \mathrm{mmol} / \mathrm{l}$ at 24 hours age, followed by an increase to $2.24 \mathrm{mmol} / \mathrm{l}$ at one week. Plasma phosphate concentration at 1 week was raised $(2.0 \mathrm{mmol} / \mathrm{l})$ and plasma alkaline phosphatase activity within the range normally observed in preterm infants $(315 \mathrm{U} / \mathrm{l})$.

\section{Discussion}

These twins are the first reported cases of abnormal bone mineralisation in the twin to twin transfusion syndrome. The radiological, absorptiometric, and biochemical abnormalities observed represent a profound disturbance of mineral homoeostasis in both infants. The biochemical data for twin 1 are suggestive of hyperparathyroidism; however, apart from the osteopenia, the radiological evidence for this is slender, and it is also unlikely that the opposite defect would be present in the other twin.

At follow up, the bone mineral content and anthropometric measurements for each twin tended to a mean appropriate for their postconceptional and postnatal ages, indicating a resolution of their common problem.

The cells responsible for the resorption of bone mineral are osteoclasts, ${ }^{5}$ which are multinucleated giant cells produced by the fusion of activated macrophages. Reduced osteoclastic activity has been identified as the cause of osteopetrosis, ${ }^{6}$ with the different forms of the disorder reflecting specific enzymic or maturational defects. The gross appearance of the bones in this disorder is similar to that observed in twin 2. Overactivity of osteoclasts, as occurs in hyperparathyroidism, leads to greatly increased bone mineral resorption, with reduced cortical thickness, as observed in twin $1 .^{5}$

We speculate that reduced availability of macrophages for activation and transformation to osteoclasts in the anaemic twin, with the reverse situation for the plethoric twin, resulted in the changes observed here, the problem resolving as normal populations of osteoclasts were established in each infant postnatally.

1 Koivisto M, Jouppila P, Kauppila A, Moilanen I, Ylikorkala . Twin pregnancy. Neonatal morbidity and mortality Acta Obstet Gynecol Scand [Suppl] 1975;44:21-9.

2 Sekiya S, Hafez ES. Physiomorphology of twin transfusion syndrome. A study of 86 twin gestations. Obstet Gynecol 1977;50:288-92.

3 O'Brien PJ, Hay DA. Birthweight differences, the transfusion syndrome, and the cognitive development of mono-
zygotic twins. Acta Genet Med Gemellol (Roma) 1987;36: zygotic

4 Greer F, McCormick A. Bone growth with low mineral ontent in very low birthweight premature infants. Pediatr Res 1986;20:925-8.

5 Mundy GR, Roodman GD. Osteoclast ontogeny and function. In: Peck WA, ed. Bone and mineral research. Vol 5. tion. In: Peck WA, ed. Bone and mint
Amsterdam: Elsevier, 1987:209-80.

6 Marks SC. Osteopetrosis-multiple pathways for the interception of osteoclast function. Appl Pathol 1987;5:172-83. 